\title{
Opinion
}

\section{Education for professional leadership and the humanities: exhortations and demonstrations}

\author{
Peter Kaufman \\ Jepson School of Leadership Studies, University of Richmond, VA and Professor Emeritus, University of \\ North Carolina, Chapel Hill, NC, USA
}

In recent years, as preparation for the professions takes up an increasing share of undergraduate curricular space, courses in the arts and humanities are increasingly viewed as expendable and ephemeral. This, it is argued here, is a mistake. The arts and humanities are good not simply in themselves, but as part of an education in human motives, beliefs, values, and interactions that can enable people to engage more deeply with the human elements of their chosen professions. Courses in the arts and humanities raise hard questions, make ethical considerations explicit, and push students to assess the standards for entry and for measuring success in professions so that honorable objectives can be identified, pursued, and defended against pressures associated with unreflective mastery and manipulation.

Keywords: arts and humanities, leadership, undergraduate curricula, professional education, Augustine, reorientation, performative and transformative challenges

The complaint: pre-professional, para-professional, and professional programs occupy large slabs of the undergraduate curricula in colleges and universities in the United States. Core courses in which the arts and humanities were introduced to first- and second-year students are extinct in places, replaced by distribution requirements or specialized seminars that occasionally - but not often - expose students to a broad range of studies from classics to cultural anthropology, history, philosophy, music, literature, political theory, and other precincts in the liberal arts. Undergraduates wishing to enter the professional programs in journalism, business (finance, accounting, and marketing), education, energy, environmental sciences, health care, and health sciences fill their 'dance cards' during their initial two years with prerequisites; then, successful, they complete their undergraduate educations, rarely, if ever, returning to the arts and humanities for an elective. During sessions of 'lifelong learning' courses that I have been privileged to teach, I frequently hear retired professionals lament that they had been yanked from the liberal arts into prescribed pre- or para-professional studies to regain consciousness only after returning, late in - or at the conclusion of - their careers, to art history, comparative religion, medievalia, philosophy, or somesuch.

The challenge, as Geoffrey Harpham (2011, pp. 124-125) sees it, and I concur: 'how to integrate the speculative, probing, exploratory critical spirit of the liberal arts with the more worldly, results-driven orientation of professional education. And, of course, to persuade all constituencies that the proposed solution does not 
degrade, dilute, or compromise the integrity of either the liberal arts or professional education, but actually realizes the full capacities of each in a way that neither could achieve on its own.'

The conceit: meeting the challenge and integrating the arts and humanities with preparation for the professions will enable undergraduates not simply to enter but to lead the latter. Before proceeding to elaborate this claim or 'conceit' - and to suggest why the type of leadership informed and inspired by greater familiarity with the humanities would contribute to our workplaces and our world and would be an invaluable asset towards adapting professional practices and professionals' ambitions and satisfactions to an ever-changing set of expectations - a more general definition of leadership seems appropriate. For my purposes, one borrowed from columnist and pundit David Brooks serves splendidly. Brooks (2014, p. A25) proposes that leadership 'begins with a warm gratitude toward that which [we] have inherited and a fervent wish to steward it well. It is propelled by an ardent moral imagination, a vision of a good society that can't be realized in one lifetime. It is informed by seasoned affections, a love of the way certain people are [and were] and a desire to give all a chance to live at their highest level.'

The complaint, challenge, and conceit might be woven into mission statements for those who are interested in campaigning for a larger role for the arts and humanities in professional education and leadership studies. Instructors, of course, will register objections. What is often called 'the instrumental value' of the liberal arts stirs resentments and reservations among many who study them assiduously and prepare to teach them. Before responding, we should acknowledge some of the protests.

The first starts with a suspicion that the mission, in effect, will reduce the liberal arts to a service role on campuses and will risk sabotaging arguments made for the intrinsic value of studies - arguments that certain disciplines have circulated among undergraduates who major in them and graduate students who anticipate teaching them. Better to find a tenured corner of the liberal arts on campus, deepen your appreciation for your area of expertise, and, as Stanley Fish (2008) advises, 'save the world on your own time.' The second set of discontented humanists rightly suggests that missions statements are usually predictable and platitudinous - tolerable, if succinct, but seldom signifying anything significant. They may articulate widely held interests among instructors in the liberal arts in showcasing humanities scholarship across their campuses and regions, yet mission statements formulated with that aim in mind never seem to answer the question, 'why.' The third and perhaps most damaging criticism is that those who subscribe to the mission of linking humanities, leadership studies, and professional education have yet to persuade professional educators that the arts and humanities are important for the development of leadership programs within their curricula. Critics among our confederates in the arts and humanities have been known to say that their colleagues in professional education want little or nothing to do with them. Save for a few small boutique colleges, campuses treat the liberal arts as a prelude to important stuff: the pre-professional programs that prepare undergraduates for careers in health care, business, engineering, and the like.

The general sentiment prompting colleagues in the liberal arts to register one or more of these reservations and colleagues in the professions to minimize the usefulness of the arts and humanities for their practices is that the humanities traffic in interpretation (often of the arts), whereas social sciences and a variety of courses even more directly related to preparation for the professions spawn proofs and truths. Louis Menand (2010, pp. 43-57) mentions that Charles Williams Eliot, president of Harvard from 1869 to 1909 , tried for those 40 years to put an impenetrable wall between liberalization and professionalization, between the liberal arts and education 
for the professions. Menand disapproves, yet the interdisciplinarity he advances as a remedy seems to me too tame. Given the commercialization of higher education, I will counsel a radical, transgressive alternative. ${ }^{1}$

Yet our interlocutors' objections have not been answered. Terms like 'transgressive' ought not to be tossed into the mix before trying to arouse those comfortable luxuriating in the liberal arts with a disinclination to dismantle Eliot's 'wall.' Stanley Fish who, as noted, makes leadership in the workplace and world an extracurricular concern ('save the world on your own time') can be taken as their paladin. 'Beware of ends,' he says, echoing Jacques Derrida. 'Beware of doing something for a reward external to its own economy. Do it because it is its own reward, and look for no pleasure beyond the pleasure of responsible, rigorous performance.' Seemingly so simple and, for many in the humanities, so seductive, the phrase, 'its own reward,' conjures up not only commonplace declarations about the intrinsic value of the liberal arts but also efforts to find tenured pockets in departments with declining enrolments in which one might hibernate - away from professional and pre-professional programs on our campuses that have been collecting majors and crowding out arts and humanities courses in general education (gen-ed) curricula. Fish issues shrill advisories against 'foreign venues,' which - truth be told - do not invariably enrich pedagogy in the arts and humanities. The lectern is not a pulpit, yet the undergraduate classrooms walled off from the careers that many of those who will fill unlikely will develop those virtues we shall shortly identify with leadership in the professions and surely will not solicit would-be and could-be collaborators among our colleagues in pre-professional and professional programs. The wall between the liberal arts and the professions will remain as long as those dug in on one side declare that 'once you start ... engaging your students in discussions designed to produce action in the world, you are doing something, but it is not academic.' But Fish is emphatic ('save the world on your own time') and excessive, suggesting that 'there is little evidence that literary study has made much difference in the injustice that permeates our world' and promptly adding parenthetically: 'to me [Fish], that's the good news' (Fish 2008, pp. 169-170 and 177-178).

The second objection, that mission statements amount to little more than rhetorical flourishes, can be rather handily answered by studies that critics come to admire, by empirical proof that studies in the arts and humanities develop sensibilities and skills that can be useful in the professions. Postponing a thorough discussion of utility and leadership, we might glance at recent research that appeared in last year's Science, confirming that 'the capacity to identify and understand others' subjective states ... allow[s] successful negotiation of complex social relationships' and increases after reading 'literary fiction' - as opposed, in the experiments, to reading non-fiction and to non-reading. 'Literary fiction,' according to researchers at the New School in New York - David Comer Kidd and Emanuele Castano (2013, pp. 377-378) - 'triggers' the sensibilities needed to sift more thoughtfully social experiences that are 'scripted by convention and informed by stereotypes.' These sensibilities, as I shall argue and illustrate later, enrich professionals' personal lives and also encourage leaders in their professions to translate the poetry of high aspiration (in line, color, drama, story, and history), with the skills and knowledge acquired during their studies in the liberal arts, into the prose of effective governance. ${ }^{2}$

1. Borrowing from Robert Frost (1956, p. 47), I have become that 'something that doesn't love a wall that sends the frozen-ground-swell under it ... That wants it down.'

2. See also Mar and Oatley (2008). 
But scholars in the arts and humanities know the aforementioned wall has often been mended in the past to keep the liberal arts from interfering with commerce and progress. In 1851, Henry Philip Tappan, first president of the University of Michigan, said that 'the commercial spirit of the country and the avenues to wealth which are opened before enterprise create a distaste for study deeply inimical to higher education. ${ }^{3}$ The remark seems to substantiate the third objection, that the educators preparing their students for many professions do not want more than a minimum of the arts and humanities. But, having discussed that presumed preference with colleagues in business schools in North America and Europe, I learned quite the contrary. ${ }^{4}$ And what I discovered would likely apply to the relationship between the liberal arts and preparation for careers in health care, public policy, law, journalism, information sciences, media studies, engineering or environmental management - and even to preparation for the professoriate:

1. Global markets and marketing, as well as ecological concerns, should have professionals lifting their horizons, but every decision in banking and trade as well as the delivery of services ranging from health care and horticulture to legal counsel or cultural literacy gets referred to the bottom line.

2. Students in professional schools network rather than befriend. The climate is chillier and, more often than not, self-interest governs network maintenance, which gives ethicists among our fellow educators, who happen to be situated in professional schools, fits.

3. This is because they face nearly intractable problems, preparing students (with recycled case studies) to tackle unanticipated issues. The world is a work in progress (or regress). Crises-yet-to-be-dreamed await. So, colleagues in our professional schools tell me, there is a need to cultivate among students an awareness of the moral life as something more firmly grounded than a set of regulations or rules. Otherwise, corporate social responsibility will become what cynics long suspected it was: a superficial ploy to maintain corporate respectability.

4. Finally, and most important, curricula in undergraduate professional programs are constructed to help prospective professionals meet the performative challenges leaders inevitably encounter. ${ }^{5}$ Their students learn to manage. They acquire skills to monitor and manage consumers, product, stakeholders, and suppliers, even competitors - not to mention their retainers or employees. Hence, professionals-in-training, my sources tell me, do not engage a critique of the dominant economic, social, and ecological orders, which could encourage them to implement worthwhile paradigmatic changes in their professions' practices. If one mixes and mingles conversations about Michaelangelo and Machiavelli with courses that qualify undergraduates to maintain a steady, resolute, and informed focus on maintenance tasks - on the performative - is it inconceivable that they would be better prepared to appreciate when and why their times or tasks call for something transformative? An affirmative is only beyond imagination, if one's imagining has yet to be transformed!

3. Quoted in Kirp (2003, p. 255).

4. I am particularly grateful to colleagues at the Nyenrode Business Universiteit in Amsterdam and the Harvard Business School.

5. Garcia (2009, pp. 119-127) discusses the different 'levels of criticality' elicited by what he calls 'performative' and 'reformative curriculum interests in leadership.' 
It is time to add demonstration to exhortation. I am not a Blake scholar, but the first half of his poem 'London' invites readers rapturously uncritical about entrepreneurship's performative challenges to reflect on the way their 'chartered' and charted career paths could become ruts:

I wander through each chartered street

Near where the chartered Thames does flow,

And mark in every face I meet

Marks of weakness, marks of woe.

In every cry of every man,

In every infant's cry of fear,

In every voice; in every ban,

The mind-forged manacles I hear. (Blake 2007, p. 220)

We become chained to professional practices - in the academy - conferences, committees, routines, ruts, more committees, forms, and more forms. Might we call them 'manacles'? Some would, and, curtly, blame the ties that bind on others. Many professors and professionals in a variety of practices believe that they are victimized by custom or the economy or 'the system.' These are authors of our woes - of our weakness. But Blake seems to make us co-conspirators in our servitudes. Perhaps, students who discuss 'mind-forged manacles' in professions they propose to enter as well as standards for entry or for measuring success, might grow sufficiently self-conscious to write, subscribe to, or - best of all - to avoid having to compose the following manifesto that some attorneys published years ago. It pillories their professional practices, their professionalism, which replaced the honorable objectives of disinterested inquiry with emphases on mastery and manipulation.

We have become acculturated to an unnecessarily limiting way of seeing and experiencing law and lawyering, a way which can separate lawyers from their sense of humanity and their own values. When that separation occurs, the profession easily becomes experienced as only a job or role, and human problems as only legal issues. Care and responsibility yield to exigencies and strategems; and the legal education, instead of reflecting the aspiration and searching that embody law and lawyering, can all too easily become an exercise in attempted mastery and growing cynicism. (Dvorkin et al. 1981, quoted in Fish 1989, p. 217)

I teach Shakespeare's Coriolanus. I do not abdicate my custodial responsibilities. My students learn about early republican Rome, as it was repossessed by Livy and Plutarch. They also learn about the absolutisms of Queen Elizabeth I, who was fond of participating in processions and sitting for her portraits - marketing majesty - and of King James I, who kept a lower profile yet professed divine right to rule. My classes consider whether the early seventeenth-century commoners' struggles for control at the parish church of St Saviors (now Southwark cathedral - the church where Edmund, brother to the bard, is interred - still a short walk from the Globe) affected the way the Roman proles were portrayed in the play, manipulated by Shakespeare's tribunes, Coriolanus' nemeses. And I teach several interpretive controversies, but then, taking the text from its historical and historiographical contexts, I ask students to contemplate what 'nobility' may have meant for Coriolanus - and means for them. I ask when and why they value candor in their leaders. Is truth-telling an indispensable virtue for leaders who may have contempt for those they lead? Do we deserve our leaders' contempt? Are our 'tribunes' any less manipulative and self-interested than those in Coriolanus?

Colleagues occasionally respond dismissively to instructors who use the arts and humanities to raise ostensibly perennial questions about the conduct of government 
or commerce, especially when a conversation tends toward criticism of current leadership. And in some quarters it has been (and still is) axiomatic that 'politics is the highest art. The sculptor shapes only the dead stone, and the poet shapes only the dead word [an sich tot ist]. But the statesman shapes the masses, gives them statute and stature, breathing into them life and form so that a people arises from them.' Thus said Joseph Goebbels in May 1933. ${ }^{6}$ In the arts and humanities, we are custodians of pasts, which are not always welcome guests in the present - in the professions but pasts will always be informative, and those who escort them into our parlors and classrooms tell tales that may often intrigue professionals and give their practices a pedigree and dignity to which they may well have been oblivious. For example, many entrepreneurs in Amsterdam who cherish their Rembrandts in the Rijksmuseum seem not to have heard that the painter was expert at building a brand and at self-commodification. Nor is it widely known that, in Amsterdam and Antwerp, professionals with an eye on the pan-European markets and a desire to attract into their precincts the best craftsmen of nearly all confessional stripes look to have done as much as or more than theorists who ordinarily get credit for promoting liberal political values and religious tolerance (Alpers 1988; Woltjer 1994; Frijhoff 2002; Tracy 2008).

It is hard to disagree that the arts and humanities, at their best, get us thinking about authority, community, and personality. Combining archival excavation with creative imagination, colleagues in the liberal arts enlighten and, on rare but precious occasions, enchant - but also shock and, more important, equip undergraduates to deal with shock and with new light ceaselessly shed on their professional lives and on their lives as citizens. Mark Edmundson (2013, pp. 62-63) refers to this challenge as 'navigating experience' and somewhat surprisingly suggests that it would be helpful, as we teach students to navigate, to toss them off course. On that count, Edmundson comes pretty close to endorsing my insistence that it is incumbent upon the arts and humanities to shock, to defamaliarize. That duty corresponds with what proponents of the so-called gymnastics argument for the liberal arts consider their aim, to train their students to cope with enigmatic fictions, irony, and misdirection, all of which, in the texts they teach, stories they tell, artifacts they introduce, and comparisons they make or explain replace the weights and treadmills. The mind is a muscle; the goal, intellectual agility.

In some forms, the gymnastics argument can be easily parodied. Sociologist Andrew Abbott snappishly recalls that Oxbridge dons and fellows insisted Greek phonemes would help their students rule India, as if subjunctives had some connection with the aspirations of subaltern populations. That past - and much else about Oxford and Cambridge - is intransigently and charmingly old-fashioned, but the agility required to confront and master problems within the professions could be acquired by our students wrestling with Dali or Dvorak, wrestling with plausible, persuasive presentations of what they might have had in mind or with what they put in our minds. ${ }^{7}$ What shall we make of it when Erasmus has Folly praise herself or when Thomas More creates a character called Nonsense (Hythloday) to put before the readers of his Utopia disagreeable truths about early modern political culture? Machiavelli likely composed his Prince to appease and please a powerful patron, yet should we take it as political satire or political science? Does Edward Hopper paint to criticize alienation or celebrate the virtue of solitude? Arguably, some classics are classics because they are infinitely interpretable riddles. They summon our abilities to solve puzzles plausibly and persuasively. Balancing options, proposing and puncturing

6. Quoted in August (1973, pp. 94-95).

7. Compare Abbott (2003). 
tried-yet-less-than-true conclusions, placing them in the context of lively conversations - which, ideally, are informed by their contexts but also by our prejudices and presuppositions about social harmony, individuality, sovereignty, tyranny, and integrity - cannot but increase our dexterity.

Rita Felski's close reading of Edith Wharton's The House of Mirth catches the protagonist's - Lily Bart's - missteps and misreads as well as 'the minute details of milieu and moment,' figures of speech, 'filaments of thought,' and protocols of the fashionable - their innuendos, snobberies, covert cruelties - all of which indicate subtly how a culture spells success and reproduces itself through 'the accretion of endless particulars and the steady accumulation of microscopic judgments' (Felski 2008, pp. 87-89). Turning to The House of Mirth with Felski's observations in mind, we might see how Wharton's novel bears on predicaments she could not have foreseen: our predicaments. When we read (Wharton 1990, p. 91) that the abhorrent Gus 'Trenor's gaze merge[s] itself in the general stream of admiring looks of which she [Lily] felt herself the center,' we know Lily is too close to her class to know the real social reality, as we may be close (too close?) to our society and its professional practices to recognize our mind-forged manacles - until we see Lily's! What we read and, as far as possible, experience about other times and places (Picasso's 'Guernica,' Goya's 'The Third of May,' Prokofiev's 'Nevsky,' Eisenstein's 'Nevsky') trains us to discover - and we train our undergraduates to discover - as did the lawyers Fish quoted, that 'they become acculturated to an unnecessarily limited way of seeing and experiencing.'

So much (for now) for intellectual agility; Martha Nussbaum's appraisal of the limits of what she calls the 'calculating intellect,' suggests that agility - left to calculating, preparing, and reacting - will not be enough. It will remain 'undiscriminating,' Nussbaum says, unless accompanied by 'vivid empath[ic] imagining,' unless the agile can imagine 'what it is really like to live a different sort of life.' Only poorly prepared professionals arrive abruptly and inopportunely at the realization that their patients, retainers, clients, and consumers live different sorts of lives. Nussbaum's telltale emphasis on empathy here and elsewhere in her interpretations of opera and poetry as well as fiction betrays her hopes for some breakthrough to social justice. She urges readers to take the full measure of others' adversity, advising that the arts and humanities knit into the fabrics of professional education can help. Her colleagues at the University of Chicago, Gary Becker and Richard Posner, respectively were and are at the forefront of what scholars now call 'the law and economics movement,' which depicts ordinary people as 'rational maximizers of satisfactions' (Posner's term). And instruction in many schools of business, finance, and -with Posner - public policy and law reflects that, to Nussbaum and to me, irrational choice. Her antidote is Dickens, specifically the novelist's Hard Times, which brings schoolmaster Thomas Gradgrind's crude, ruthlessly utilitarian modus vivendi into the world of our students heading for the professions. They will 'notice Gradgrind's economics has an even greater hold over the political and intellectual life of [our] society,' Nussbaum says, regretting 'that the ... cost benefit analysis favored by economics has become so familiar in public policy that it is taken for granted. At the same time, public servants are less and less likely to be readers of the literature, where they would discover a more complex vision of human life.' Building a wall between the liberal arts and education for the professions is, plausibly, responsible for Nussbaum's 'less and less likely,' as has shrinking the curricular space allocated to the arts and humanities in undergraduates' pre-professional trajectories (Nussbaum 1995, pp. 18-19, 46-49, 66-72, and 89-94). 
Colleagues convinced public spaces rather than curricular spaces would better meet society's needs for solidarity, compassion, and conversation are unlikely to swivel and support proposals offered here, yet sociologist and historian Richard Madsen confirms that a liberal education was and should be the 'public space' in which professional and political leadership is incubated. The arts and humanities 'used to be thought of as ways to produce a vital cultural center, a normative core for public discussion based on the values of broadmindedness,' he says, 'based on humility gained through an experience of the full complex of reality and a zest for innovation balanced by respect for tradition' (Madsen 1993, p. 511). He concludes that 'an articulate, coherent, responsible Left and Right depend on the sustenance of such a vital center' (ibid.). To be sure, polarizing Rights and Lefts are likely to give ground reluctantly, if at all. Still, the humanities may be the best place (or 'space') to seek common ground - Madsen's 'normative core' when polarization in the media and in other 'public spaces' is the rule. To make that point when discussions of education are all about measurement and assessment - in my humble yet outraged opinion - we ought to consider teaching transgressively. ${ }^{8}$

Transgressive teaching and research in the liberal arts, of course, are hardly unprecedented. To retrieve and often ennoble the marginalized, the arts and humanities are known to have disclosed the undertows in hegemonic discourses and in the familiar western narratives of liberalism. To teach to transgress is to defamaliarize, to re-narrativize responsibly such things as the histories of immigration, of imperialism, or of movements and leaders conventionally vilified or lionized. Many novels and canvasses transgress but require our help in the arts and humanities to complete their tasks. Goya's 'Third of May,' for one, with its depiction of a piston-like firing squad, featuring soldiers as impersonal as drones, not only calls for contextualization but for application, as the allusion to 'drones' suggests. And Robert Frost's (1956, p. 47) poem, 'Mending Wall' contains the line, 'good fences make good neighbors,' the truth of which is often taken for granted and taken as Frost's final word, but a transgressive reading summons another possibility and catches Frost questioning whether we build (and redistrict) to keep a them out or to wall us in. My point is that instructors in the arts and humanities are needed not just to help undergraduates decode Warhol and Brecht or Milton and Cicero but also to complete texts' and artifacts' transgressions. Meeting that challenge should also help our student colleagues develop agility, but it requires historical context and conversation, critical reflection enabling us to see how characters, colors, symphonies, and scripts undermine facile generalizations or impeach embedded social and professional practices.

Michael Roth's recent book, Beyond the University (2014) suggests a tame version of what I advocate as the contribution of the arts and humanities to transformative leadership in the professions: (1) the custodial role of the humanities; (2) the gymnastics argument for intellectual agility; and (3) the burden of the liberal arts to marinate character and make compassion more expansive. During the first 60 or so years of the twentieth century, Roth says, scholars in the United States took up such 'burdens' and accepted such arguments and roles, but that changed when the arts and humanities were eclipsed by a set of required courses in the natural and social sciences that were construed as better for business or law or health care careers. 'People were asking,' Roth continues, 'whether traditional ideas of liberal education were merely archaic vestiges of a mode of education that should be left behind' (ibid., p. 125).

Whenever I lecture on Augustine, I run into currents that colleagues in the social and natural sciences would consider well offshore, no matter how dubious they may be

8. For 'public spaces,' see Thuma (2011). 
about the expressions of American exceptionalism that seem always in season. Teaching Augustine transgressively in times of triumphalism is particularly appropriate. For the prelate who became an influential bishop in North Africa after having worked in Italy as what we might call a publicist, promoting his and his clients' political careers, can be quite enlightening about the ambitions and pretensions of statesmen that attend their successes and precede their falls. Augustine was well acquainted with the exaggerated predictions that followed Emperor Constantine's conversion to Christianity in the early fourth century. He and his Christian contemporaries nonetheless came to realize that their God, for unfathomable reasons, hitched their faith to an empire, the western part of which was rapidly disintegrating (Ward-Perkins 2005). Civic-spirited Romans from Gaul to Galatia had thought their empire was exceptional - sine fine, eternal - an empire with a manifest destiny (Kah 1989). Augustine recoiled from both the celebrations and the despair that followed. He set out to reorient readers, to reassess Rome's expansion from the early innings of the republic nearly to the last at bat in the West in the fifth century, and to re-enchant his faith's future (Kaufman 2007, pp. 11-39 and 118-132; Kaufman 2012).

Augustine wrote about patriots moved to build and maintain reputations. Name, fame, and glory were critical. But, pursuing them, the Romans displayed their inordinate desires to acquire, which Augustine called concupiscence, a lust to be first (principandi libidine), and a lust to dominate (dominandi libido) (Augustine 1955, 14.28; Augustine 1981, 3.18). In effect, his analyses of the empire's fate and of the psychology of imperialism did what Wittgenstein would have the humanities do, 'go right down to the foundations [and] put the question marks deep enough down' (Wittgenstein 1980, p. 62). Augustine has been celebrated for much more. He contested sectarian impulses, put self-promoting, charismatic rivals in their places, and argued against colleagues who minimized human imperfection. He contributed meaningfully to secular and religious theorists alike who stand watch on the frontier between church and state. And unlike poets who tended to cross that frontier (Kah 1989, p. 231), Augustine refortified it and suppressed passions and pieties associated with nationalism and exceptionalism. He can assist us to evaluate the desires that drive our business as usual, as he did Rome's, and he introduces a wholly other (as well as, for him, a holy other) concept of commonwealth to replace political lusts and to attenuate the torment and disappointment that normally follows the collapse of favored enterprises. Recoil, reorientation, re-enchantment, and resilience; Augustine looked to build resilience.

Specifically, Augustine proposed changing the rules for the faithful. They would live as pilgrims, as resident aliens. They would see things differently, cling less tenaciously - if cling at all - to possessions that linked them to this world's lesser goods. He tried to break the mind-forged manacles of his readers and auditors. Pilgrims would come to see such loves amounted to self-love and were inferior to the love of the faithful for the world - for their neighbors, broadly conceived - for creation, which paid forward God's love for them. What makes Augustine's pilgrims (and Augustine) contemporary is not their cumulative importance for the fate and shape of Christianity in subsequent centuries but their rejection of dejection and their willingness and abilities to rebound from both exceptionalism and its discontents, and by their abilities critically to affirm the traditional and radically to alter its trajectory as well as the course of their lives (Dyson 2001; Mathewes 2010). ${ }^{9}$

9. Introspection, 'soliloquies,' and conversations with learned friends were of paramount importance to Augustine. He prized his colloquys with friends in his brief retreats to Cassiciacum and Thagaste before becoming bishop. See, for example, Stock (2010, pp. 190-191). Inglebert (1998) discusses the fate of Christian triumphalists in Augustine's sermons. 
Stephanie Lemenager and Stephanie Foote, in a recent essay, could have been talking about Augustine, but they had in mind the humanities, which, they say, 'are especially suited to speak of the rhetoric of crisis because they demand that we understand how narratives about place, and about value, and about the relation of social actors to those ideas are made' (Lemenager and Foote 2012, pp. 575-576). Maybe we should add 'and re-made.' Hence, we have yet another reason to commend the humanities to colleagues in pre-professional, para-professional, and professional undergraduate programs whose recent graduates weathered economic and political crises, not to mention personal crises such as the one that motivated the lawyers' lament quoted above, and whose current students are bound to experience more of the same.

The alternative, of course, is to ignore or simply bark at unwelcome data about suburban sprawl, climate change, and inequitable distributions of resources, political gridlock, and such. Or, should disposition permit, one could accept the seemingly fraudulent claims that all is well and that transformative leadership and paradigmatic changes are unnecessary as well as undesirable. Recoil, reorientation, and resilience, optimists may propose, are and will be unrequired. Yet, even if a case could be made that crisis-talk is petulant rather than to-the-point, colleagues in the liberal arts have work to do within their disciplines and divisions. Specialized scholarship, when not impenetrable, is often far removed from what preparation for the professions requires. Elite arts and humanities are too contemptuous of what Toby Miller (2012, pp. 71-72) calls 'populist humanities' - media studies and the like - which have a direct bearing on education for many of the professions concerned with 'branding' and image as well as market share and which - practiced daringly and readably may assist others in the liberal arts to forsake the 'safely sidelined critique' that, according to Miller, characterizes efforts of the traditional disciplines to be useful.

'Sure he that made us with such large discourse, looking before and after, gave us not that capability and godlike reason to fust in us unused' or 'sidelined.' Hamlet's soliloquy is a suitable way to bring us to an end without indulging in polemic. The scene finds Hamlet contemplating his nearly interminably delayed revenge as he watches a Norwegian army marching through Denmark to Poland 'expos[ing] what is mortal and unsure to all that fortune, death, and danger dare - even for an eggshell.' Hamlet's pauses compare unfavorably, in his mind, to Norway's determination to bleed for a plot in Poland, raising the question for Shakespeare's twenty-first century audiences - yet less likely, for their Jacobean predecessors - whether conscience made him a coward or revenge and a silly quarrel made Norway invidiously aggressive. Hamlet has no doubt. 'Rightly to be great is not to stir without great argument, but greatly to find quarrel in a straw when honor's at stake.' The question and Hamlet's predicament leave us with a set of enduring dilemmas. For one, how honorable is honor that requires revenge? But the statement that introduces the protagonist's self-lacerating reflection registers, for our purposes, a challenge that the arts and humanities can ignore only at their peril (Shakespeare 1985, 4.4). 'With such large discourse, looking before and after,' do we dare avoid problematizing received wisdom? Hamlet, to his peril, ultimately confronted injustices, goaded rapier-first, and somewhat indiscriminately. 'With such large discourse,' the liberal arts, arguably, have a responsibility to prompt undergraduates to consider how to live well, while they decide how and prepare to earn a living and how to avoid the acculturation and 'growing cynicism' deplored by those, who, as the lawyers quoted, regretted 'yield[ing] to exigencies.'

Colleagues in the arts and humanities have been known to give up. They admit the utility of their 'large discourse[s]' but assume undergraduates are uninterested in intellectual rigor. Intellectual agility allegedly has far less cachet on our campuses than the 
coordination it takes to score in sports or video games. Defeatism of this sort can be contagious, but, as Andrew Delbanco counsels, trust in our undergraduates can pay dividends. 'Whether they study accounting or philosophy, hotel management or history, the vast majority of our college undergraduates,' he insists, 'are capable of engaging the big questions - questions of truth, responsibility, justice, beauty, among others' formerly conceded to be at 'the center of college education'. 'We are too quick to assume,' Delbanco concludes, 'that students with lesser preparation are unfit for education in this enlarging sense' (Delbanco 2012, pp. 173-174).

Moreover, transgressive teaching, done well, tantalizes. Complacency is contagious; contrarians are few, yet scrappier students are generally ready to interrogate their own predispositions. To borrow from Stefan Collini's study of impeccably transgressive colleagues, John Ruskin and F.R. Leavis, teaching that dares to be dismissive and rude can enable and clarify 'the convictions of those who already feel intuitive reservations about the conventional' (Collini 2013, p. 13). Easier, probably, yet effective in challenging the dominant discourses in pre-professional programs, undergraduates might be tempted by arts and humanities instructors to agree with Oliver Wendell Holmes's comment to a senior at Harvard, that life 'is painting a picture, not doing a sum'. 'You have to make the romance,' Holmes finished, 'and it will come to the question how much fire you have in your belly' (quoted in Biddle 1942, pp. 138-139).

That romance and 'fire' as well as Augustine's recoil, reorientation, and resilience may apply generally to life in the boardrooms, backrooms, and backyards, but it certainly applies to - and fuels - transgressive teaching. To be sure, should the liberal arts give over too much to transgressive tasks, they could forfeit close reading (a terrible shame) and they would risk self-indulgence as well as superficiality. But, if educators in the arts and humanities give too little, they will be poorly positioned to assist their undergraduates to prepare insightfully and comprehensively for the transformative challenges they will almost certainly encounter as leaders in their professions: envisioning and implementing paradigmatic changes with poise, confidence, discipline, intelligence, integrity, and compassion. In my experience, teaching transgressively to good effect and 'mak[ing] the romance' starts simply (and restarts again) whenever we treat our undergraduates as intellectuals rather than as consumers.

'With such large discourse,' we ought not to let it 'fust in us' or in them 'unused.'

\section{REFERENCES}

Abbott, Andrew (2003), 'The Zen of Education,' University of Chicago Magazine, 96, accessible at: magazine.uchicago.edu/0310/features/zen.shtml.

Alpers, Svetlana (1988), Rembrandt's Enterprise: The Studio and the Market, Chicago: The University of Chicago Press.

August, Wolf-Eberhard (1973), Die Stellung der Schauspieler im Dritten Reich: Versuch einer Darstellung der Kunst und Gesellschaftspolitik in einem totalitären Staat am Beispiel des Berufsschauspielers, Cologne: Universität zu Köln.

Augustine (1955), De civitate Dei, Corpus Christianorum series Latina, B. Dombart and A. Kalb (eds), Turnhout: Brepols.

Augustine (1981), Confessionum libri XIII, Corpus Christianorum series Latina, L. Verheijen (ed.), Turnout: Brepols.

Biddle, Francis (1942), Mr. Justice Holmes, New York: Charles Scribner's Sons.

Blake, William (2007), Blake: The Complete Poems, W.H. Stevenson (ed.), London: Pearson Longman.

Brooks, David (2014), 'The Leadership Emotions,' The New York Times, April 21. 
Collini, Stefan (2013), 'What Ultimately For? The Elusive Goal of Cultural Criticism,' Raritan, 33, 4-26.

Delbanco, Andrew (2012), College: What It Was, Is, and Should Be, Princeton, NJ: Princeton University Press.

Dvorkin, Elizabeth, Himmelstein, Jack, and Lesnick, Howard (1981), Becoming a Lawyer: A Humanistic Perspective on Legal Education and Professionalism, Eagan, MN: West.

Dyson, R.W. (2001), The Pilgrim City: Social and Political Ideas in the Writings of St. Augustine of Hippo, London: Boydell Press.

Edmundson, Mark (2013), Why Teach: In Defense of Real Education, London: Bloomsbury.

Felski, Rita (2008), Uses of Literature, Oxford: Blackwell.

Fish, Stanley (1989), Doing What Comes Naturally: Change, Rhetoric and the Practice of Theory in Literary and Legal Studies, Durham, NC: Duke University Press.

Fish, Stanley (2008), Save the World on Your Own Time, Oxford: Oxford University Press.

Frijhoff, Willem (2002), 'Religious Toleration in the United Provinces: From Case to Model,' in R. Po-Hsia and Henk van Nierop (eds), Calvinism and Religious Toleration in the Golden Age, Cambridge, UK: Cambridge University Press, pp. 27-52.

Frost, Robert (1956), Complete Poems of Robert Frost, New York: Holt Rinehart and Winston. Garcia, Eric Jean (2009), 'Raising Leadership Criticality in MBSs,' Higher Education, 58, 113-130.

Harpham, Geoffrey Galt (2011), The Humanities and the Dream of America, Chicago: The University of Chicago Press.

Inglebert, Hervé (1998), 'Universalité Chrétienne et Monarchie Impériale dans les Nouveaux Sermons d'Augustin Découverts à Mayence,' in Goulven Madec (ed.), Augustin Prédicateur (395-411), Paris: Institut d'Études Augustiniennes, pp. 449-470.

Kah, Marianne (1989), Die Welt der Römer mit der Seele suchend: Die Religiosität des Prudentius im Spannungsfeld zwischen Pietas Christiana und Pietas Romana, Bonn: Borengässer.

Kaufman, Peter Iver (2007), Incorrectly Political: Augustine and Thomas More, Notre Dame, IN: University of Notre Dame Press.

Kaufman, Peter Iver (2012), 'Augustine's Dystopia,' in James Wetzel (ed.), Augustine's City of God: A Critical Guide, Cambridge, UK: Cambridge University Press, pp. 55-74.

Kidd, David Comer and Castano, Emanuele (2013), 'Reading Literary Fiction Improves Theory of Mind,' Science, 342, 377-380.

Kirp, David (2003), Shakespeare, Einstein, and the Bottom Line, Berkeley, CA: University of California Press.

Lemenager, Stephanie and Foote, Stephanie (2012), 'The Sustainable Humanities,' PMLA: Publications of the Modern Language Association of America, 127, 572-578.

Madsen, Richard (1993), 'Global Monoculture, Multiculture, and Polyculture,' Social Research, 60, 493-511.

Mar, Raymond A. and Oatley, Keith (2008), 'The Function of Fiction is the Abstraction and Simulation of Social Experience,' Perspectives on Psychological Science, 3, 173-192.

Mathewes, Charles (2010), The Republic of Grace: Augustinian Thoughts for Dark Times, Grand Rapids, MI: Eerdmans.

Menand, Louis (2010), The Marketplace of Ideas, New York: W.W. Norton.

Miller, Toby (2012), Blow Up the Humanities, Philadelphia: Temple University Press.

Nussbaum, Martha Craven (1995), Poetic Justice, Boston: Beacon Press.

Roth, Michael S. (2014), Beyond the University: Why Liberal Education Matters, New Haven, CT: Yale University Press.

Shakespeare, William (1985), Hamlet, in Willard Farnham (ed.), New York: Viking Penguin.

Brian, Stock (2010), Augustine's Inner Dialogue: The Philosophical Soliloquy in Late Antiquity, Cambridge, UK: Cambridge University Press.

Thuma, Andrea (2011), 'Hannah Arendt, Agency, and the Public Space,' in M. Berensen, L. Lee, and A.S. Tekelioglu (eds), Modernities Revisited, Vienna: Institut für die Wissenschaften von Menschen, accessible at: http://www.iwm.at/publications/5-junior-visiting-fellows-conferences/ andrea-thuma-2/.

Tracy, James D. (2008), The Founding of the Dutch Republic: War, Finance, and Politics in Holland, 1572-1588, Oxford: Oxford University Press. 
Ward-Perkins, Bryan (2005), The Fall of Rome and the End of Civilization, Oxford: Oxford University Press.

Wharton, Edith (1990), The House of Mirth, in Elizabeth Ammons (ed.), New York: W.W. Norton.

Wittgenstein, Ludwig (1980), Culture and Value, G.H. Von Wright (ed.), Chicago: The University of Chicago Press.

Woltjer, J.J. (1994), Tussen Vrijheidsstrijd en Burgeroorlog: Over de Nederlandse Opstand, 1555-1580, Amsterdam: Balans. 